\title{
EVALUASI KUALITAS AIR PADA SISTEM RESIRKULASI BUDIDAYA IKAN GURAMI, Osphronemus goramy MENGGUNAKAN PEMODELAN DINAMIKA SISTEM
}

\author{
Astried Sunaryani*\#, Taofik Jasalesmana*), dan Livia Rossila Tanjung ${ }^{* *}$ \\ *) Loka Penelitian Teknologi Bersih, Badan Riset dan Inovasi Nasional \\ Jl. Sangkuriang, Bandung, 40135 \\ *) Pusat Penelitian Limnologi, Badan Riset dan Inovasi Nasional \\ Jl. Raya Jakarta-Bogor KM 46, Cibinong, Kab. Bogor 16911
}

(Naskah diterima: 22 Februari 2021; Revisi final: 18 Oktober 2021; Disetujui publikasi: 18 Oktober 2021)

\begin{abstract}
ABSTRAK
Perkembangan teknologi dalam pembudidayaan ikan menggunakan sistem resirkulasi sangat cepat dalam beberapa tahun terakhir karena bersifat ramah lingkungan dan memberikan banyak keuntungan yaitu mampu memproduksi ikan dengan kepadatan tinggi. Namun, penurunan kualitas air akibat limbah dari feses dan sisa pakan dapat membahayakan sintasan ikan. Penelitian ini dilakukan untuk mengevaluasi kualitas air, khususnya konsentrasi amonia pada sistem resirkulasi budidaya ikan gurami, Osphronemus goramy melalui pemodelan dinamika sistem. Simulasi pemodelan dilakukan dengan software Vensim PLE menggunakan data sekunder. Selama 30 hari periode simulasi, konsentrasi amonia dalam kolam ikan meningkat sampai dengan hari ke-15, kemudian turun bertahap hingga hari ke-30. Konsentrasi amonia yang aman diperoleh dari laju resirkulasi 50 dan 75 L/jam dengan sintasan ikan gurami 95\% Persentase eror sebesar 8,6\% dibandingkan dengan data hasil penelitian sebelumnya menunjukkan bahwa model dinamika sistem ini valid dan dapat digunakan untuk pemantauan kualitas air, khususnya amonia, dalam budidaya ikan gurami yang menggunakan sistem resirkulasi.
\end{abstract}

\section{KATA KUNCl: budidaya ikan gurami; model dinamika sistem; sistem resirkulasi}

ABSTRACT: Evaluation of water quality in the recirculation system of gouramy, Osphronemus goramy cultivation using system dynamics model. By: Astried Sunaryani, Taofik Jasalesmana, and Livia Rossila Tanjung

The development of recirculating aquaculture systems (RAS) has been rapidly increased in recent years due to environmental and economic advantages, i.e., the system can support farmed fish at high density. However, declining water quality in RAS could occur as a result of the accumulation and decomposition of fecal and uneaten feed materials that can be harmful to fish. This study was conducted to evaluate water quality, particularly the concentration of ammonia in the recirculation system of gouramy, Osphronemus goramy aquaculture through a system dynamics model. The model simulation was performed via Vensim PLE software using datasets from secondary sources. During the 30-days of simulation period, the ammonia concentration in the fish pond increased until day 15, then decreased gradually until day 30. Safe ammonia concentrations were obtained from recirculation rates of 50 and $75 \mathrm{~L} \mathrm{~h}^{-1}$ with gouramy survival rate of $95 \%$ The percentage error of $8.6 \%$ compared to the previous experimental data shows that the prediction of the developed system dynamics model is valid and acceptable. The model can therefore be used for water quality monitoring, particularly for ammonia concentration in gouramy farming using recirculating aquaculture systems.

\section{KEYWORDS: gouramy cultivation; system dynamics model; recirculating aquaculture system}

\section{PENDAHULUAN}

Pembudidayaan ikan dengan sistem resirkulasi (recirculating aquaculture system) merupakan salah satu

\footnotetext{
\# Korespondensi: Loka Penelitian Teknologi Bersih, Badan Riset dan Inovasi Nasional.

Jl. Sangkuriang, Bandung, 40135, Indonesia

E-mail: astried.sunaryani@ brin.go.id
}

teknologi budidaya perikanan darat yang telah banyak diterapkan secara komersial di negara-negara maju seperti Amerika Serikat, Kanada, Norwegia, Prancis, dan Jerman (Labbé et al., 2014; Meyer, 2018; Miller, 2018; Gardner Pinfold Consultants Inc., 2019; Fletcher, 2020). Prinsip pada sistem ini yaitu penggunaan kembali air untuk budidaya, sehingga pemasokan air 
dari luar sistem dapat dikurangi. Dalam sistem ini, air yang telah digunakan untuk budidaya ikan dan mengalami penurunan kualitas dapat diolah agar dapat digunakan kembali. Sistem ini merupakan teknologi budidaya yang intensif dan dapat dijadikan alternatif untuk menggantikan teknologi ekstensif, sehingga cocok untuk diterapkan di daerah yang memiliki lahan dan ketersediaan air yang terbatas (Suresh \& Lin, 1992).

Ikan gurami, Osphronemus goramy merupakan salah satu ikan yang cocok untuk dibudidayakan dengan sistem resirkulasi. Ikan ini sudah lama dibudidayakan dengan teknologi ekstensif, sangat populer sebagai ikan konsumsi, dan memiliki harga jual yang lebih mahal dibandingkan ikan air tawar yang lain (Tanjung \& Pilo, 2015). Budidaya ikan gurami dengan sistem resirkulasi akan memberikan banyak keuntungan karena penggunaan air lebih hemat, fleksibilitas lokasi budidaya, lebih higienis, kebutuhan lahan lebih sedikit, kemudahan dalam pengendalian dan pengaturan kualitas air, ramah lingkungan, terhindar dari pencemaran yang terjadi di luar sistem, dan dapat dilaksanakan sepanjang tahun (Fadhil et al., 2010; Lekang, 2013).

Salah satu permasalahan yang harus diperhatikan dalam pembudidayaan ikan gurami dengan sistem resirkulasi adalah penurunan kualitas air yang digunakan. Kualitas air dalam sistem harus tetap terjaga dalam kondisi baik, supaya ikan dapat tumbuh optimal. Dalam sistem resirkulasi, penurunan kualitas air terutama terjadi akibat limbah organik yang berasal dari feses ikan dan sisa pakan yang terlarut di dalam air. Dalam perikanan budidaya secara komersial, sebanyak $30 \%$ dari total pakan yang diberikan tidak dikonsumsi oleh ikan dan sekitar 25\%30\%dari pakan yang dikonsumsi tersebut akan diekskresikan (McDonald et al., 1996).

Fluktuasi kualitas air pada budidaya ikan gurami dengan sistem resirkulasi dapat disimulasikan menggunakan pemodelan dinamika sistem. Model ini mampu menggambarkan kondisi ideal suatu sistem dalam konteks yang sederhana, serta memprediksi beberapa variabel yang mungkin tidak dapat dihitung secara langsung. Pemodelan dinamika sistem merupakan meto de simulasi yang pada awalnya dipakai dalam menyelesaikan masalah yang terjadi dengan menggambarkan hubungan antara variable-variabel dalam suatu sistem yang kompleks (Forrester, 1994). Metode simulasi ini dapat diterapkan untuk menganalisis dinamika parameter kualitas air dalam aktivitas budidaya ikan karena terdapat karakteristik yang mungkin terjadi dari variabel-variabel yang memengaruhinya.

Menurut Forrester (1994), model dinamika sistem mampu menggambarkan keadaan yang sebenarnya, serta mampu menerima kompleksitas dan nonlinearitas. Selain itu, Fuchs (2006) menambahkan bahwa pemodelan dinamika sistem selain sederhana juga tangguh karena dapat menggabungkan ide-ide sederhana menjadi model pada berbagai sistem dan proses yang kompleks; pemodelan dinamika sistem juga berguna karena mampu menyederhanakan integrasi pemodelan dan percobaan, serta alami karena ide-ide sederhana di balik model dinamika sistem sesuai dengan bentuk dasar pemikiran manusia.

Dalam penelitian ini, parameter kualitas air yang akan dievaluasi dengan model dinamika sistem adalah amonia bebas yang tidak terionisasi $\left(\mathrm{NH}_{3}\right)$. Pemantauan keberadaan amonia dalam sistem budidaya ikan sangat penting karena amonia bersifat toksin. Ikan yang terpapar pada konsentrasi subletal amonia menunjukkan kerusakan histopatologi pada insang, hati, dan ginjal. Jaringan insang mengalami peningkatan aliran darah (hiperemia) dan pembengkakan pembuluh darah (telangiektasis). Jaringan hati menunjukkan pembengkakan karena air masuk ke dalam sel (degenerasi hidropik), sedangkan glomerulus pada jaringan ginjal mengalami peradangan atau glomerulonefritis (Benli et al., 2008). Konsentrasi amonia yang sangat tinggi di perairan juga dapat menyebabkan penurunan ekskresi amonia oleh ikan, sehingga amonia akan terakumulasi di dalam darah dan insang (Budiardi et al., 2011). Hasil penelitian Ogbonna \& Chinomso (2010) mengonfirmasi bahwa konsentrasi amonia di atas $0,20 \mathrm{mg} / \mathrm{L}$ di kolam budidaya akan membahayakan kehidupan ikan. Berdasarkan hal tersebut, maka penelitian ini dimaksudkan untuk mengevaluasi kualitas air, khususnya konsentrasi amonia, dalam kolam budidaya ikan gurami dengan sistem resirkulasi melalui pendekatan pemodelan dinamika sistem.

\section{BAHAN DAN METODE}

\section{Pengumpulan Data}

Simulasi pemodelan evaluasi kualitas air menggunakan data sekunder berupa nilai-nilai variabel yang berasal dari beberapa penelitian yang telah dilakukan dalam pembudidayaan ikan gurami dengan sistem resirkulasi. Data yang digunakan untuk formulasi model ditunjukkan dalam Tabel 1. Konsentrasi amonia di kolam budidaya disimulasikan dengan variasi laju resirkulasi 5, 10, 20, 50, dan 75 L/ jam dengan satu kali ulangan. 
Tabel 1. Nilai dan referensi yang digunakan pada model untuk setiap proses

Table 1. Values and references used in the model for each process

\begin{tabular}{|c|c|c|c|}
\hline Proses (Process) & Variabel (Variable) & Nilai (Nalue) & Referensi (Reference) \\
\hline \multirow{2}{*}{$\begin{array}{l}\text { Amonia dari feses } \\
\text { Ammonia from feces }\end{array}$} & $\begin{array}{c}\text { Fraksi } \mathrm{N} \text { di feses } \\
\text { Fraction of } \mathrm{N} \text { in feces }(\%)\end{array}$ & 2.44 & $\begin{array}{c}\text { López-Alvarado } \\
\text { (1997) }\end{array}$ \\
\hline & $\begin{array}{c}\text { Bobot ikan } \\
(\text { Fish weight })(t=0)(g)\end{array}$ & 1 & Maishela (2016) \\
\hline \multirow{3}{*}{$\begin{array}{l}\text { Amonia dari sisa pakan } \\
\text { Ammonia from uneaten } \\
\text { fish food }\end{array}$} & $\begin{array}{l}\text { Laju pemberian pakan } \\
\text { Feeding rate }\end{array}$ & $\begin{array}{l}\text { 20\%dari bobot ikan, } \\
2 \text { kali sehari } \\
20 \% \text { of fish weight, } \\
\text { twice a day }\end{array}$ & BSN (2000) \\
\hline & $\begin{array}{c}\text { Fraksi } \mathrm{N} \text { di pakan } \\
\text { Fraction of } \mathrm{N} \text { in fish food }(\%)\end{array}$ & 7.52 & $\begin{array}{c}\text { López-Alvarado } \\
\text { (1997) }\end{array}$ \\
\hline & $\begin{array}{c}\text { Pakan yang tidak dikonsumsi } \\
\text { Uneaten fish food }(\%)\end{array}$ & 43 & $\begin{array}{c}\text { Verawati et al. } \\
(2015)\end{array}$ \\
\hline \multirow{2}{*}{$\begin{array}{l}\text { Amonia keluar kolam } \\
\text { Ammonia out of pond }\end{array}$} & $\begin{array}{c}\text { Volume air kolam } \\
\text { Fish pond volume }(\mathrm{L})\end{array}$ & 72 & Maishela (2016) \\
\hline & $\begin{array}{c}\text { Laju resirkulasi } \\
\text { Recirculation rate } \\
\end{array}$ & $\begin{array}{c}5 \mathrm{~L} / \mathrm{jam} \text {, divariasi } \\
5 \mathrm{~L} \mathrm{~h}^{-1} \text {, varied }\end{array}$ & Weatherley (1982) \\
\hline $\begin{array}{l}\text { Amonia hasil filtrasi } \\
\text { Ammonia from } \\
\text { filtration }\end{array}$ & $\begin{array}{l}\text { Fraksi pengolahan amonia } \\
\text { oleh filter mekanik } \\
\text { Fraction of ammonia } \\
\text { removal by mechanical filter (\%) }\end{array}$ & 48 & Maishela (2016) \\
\hline \multirow{2}{*}{$\begin{array}{l}\text { Amonia teroksidasi } \\
\text { Oxidation of ammonia }\end{array}$} & $\begin{array}{c}\text { Konstanta laju orde } \\
\text { pertama oksidasi amonia } \\
\text { Oxidation ratefor ammonia }\end{array}$ & $\begin{array}{l}0,35 / j a m \\
0.35 \mathrm{~h}^{-1}\end{array}$ & Weatherley (1982) \\
\hline & $\begin{array}{c}\text { Volume filter biologi } \\
\text { Volume of biological filter }(\mathrm{L})\end{array}$ & 2.5 & Maishela (2016) \\
\hline $\begin{array}{l}\text { Amonia tidak terolah } \\
\text { Untreated ammonia }\end{array}$ & $\begin{array}{l}\text { Fraksi amonia tidak terolah } \\
\text { Fraction of untreated ammonia }\end{array}$ & 0.65 & Weatherley (1982) \\
\hline \multirow{2}{*}{$\begin{array}{l}\text { Kematian } \\
\text { Mortality }\end{array}$} & $\begin{array}{l}\text { Laju kematian } \\
\text { Mortality rate }\end{array}$ & $\begin{array}{c}\text { 5\%untuk konsentrasi } \\
\text { amonia } \geq 0,04 \mathrm{mg} / \mathrm{L} \\
5 \% \text { for ammonia } \\
\text { concentration } \geq 0,04 \mathrm{mg} \mathrm{L}^{-1}\end{array}$ & $\begin{array}{c}\text { Environment Canada } \\
(2001)\end{array}$ \\
\hline & $\begin{array}{l}\text { Populasi ikan gurami } \\
\text { di kolam } \\
\text { Population of gouramy } \\
\text { in fish pond }\end{array}$ & $\begin{array}{l}50 \text { ekor } \\
50 \text { fish }\end{array}$ & Maishela (2016) \\
\hline
\end{tabular}

\section{Analisis dan Formulasi Model}

Pemodelan evaluasi kualitas air pada budidaya ikan gurami dengan sistem resirkulasi disimulasikan dengan menggunakan perangkat lunak dinamika sistem Vensim PLE (Ventana System, Inc.) yang didasarkan pada beberapa asumsi dan batasan model sebagai berikut:

1. Parameter kualitas air yang disimulasikan adalah konsentrasi amonia yang tidak terionisasi $\left(\mathrm{NH}_{3}\right)$ yang terdapat di kolam budidaya ikan.
2. Amonia yang ada di kolam berasal dari feses dan sisa pakan ikan, amonia yang berasal dari hasil eksresi urin ikan tidak diperhitungkan.

3. Sistem pada kolam ikan dan filter tercampur sempurna (well mixed) dan mengikuti persamaan laju reaksi orde pertama.

4. Perubahan dinamik dari jeda waktu (timelag) antara kolam ikan dan filter yang diakibatkan oleh pipa dan pompa tidak diperhitungkan. 
5. Parameter kualitas air yang terdiri atas suhu, $\mathrm{pH}$, dan oksigen terlarut dapat memengaruhi proses nitrifikasi (Ripple, 2003). Namun pada simulasi model ini belum diperhitungkan.

6. Tidak ada penambahan dan pemindahan ikan selama satu periode simulasi.

7. Satu periode simulasi model adalah 30 hari pemeliharaan ikan pada fase pendederan kedua.

Sistem budidaya resirkulasi standar terdiri atas beberapa komponen, yaitu unit budidaya (kolam), pompa, perpipaan, filter mekanik, filter biologi, dan aerasi (Hutchinson et al., 2004). Namun, hal yang terpenting dalam sistem resirkulasi adalah proses filtrasi karena filter yang akan berfungsi sebagai unit pembersihan dan perbaikan kualitas air untuk digunakan kembali. Formulasi model pada penelitian ini terdiri atas komponen kolam ikan, filter mekanik, dan filter biologi. Tiga jenis filter yang digunakan sekaligus adalah ijuk, spons, dan pecahan karang (Maishela, 2016). Filter ijuk dan spons berperan sebagai filter mekanik, sedangkan pecahan karang digunakan sebagai filter biologi untuk media pertumbuhan bakteri. Ikan gurami yang dibudidayakan berada pada fase pendederan kedua, yaitu tingkat benih dengan kisaran ukuran 1-2 cm sampai 2-4 cm dan bobot ikan gurami saat $\mathrm{t}=0$ adalah $1 \mathrm{~g}$. Dengan periode pendederan 30 hari, bobot ikan gurami setelah satu periode menjadi $5 \mathrm{~g}$ (BSN, 2000). Ikan ditebar dengan kepadatan 50 ekor/72 L. Formulasi model disimulasikan dengan perangkat lunak Vensim PLE yang ditunjukkan dalam Gambar 1; dengan menggunakan nilai dari setiap variabel yang ditampilkan dalam Tabel 1.

Gambar 1 memperlihatkan bahwa dalam suatu siklus resirkulasi budidaya ikan gurami, konsentrasi amonia yang terdapat dalam kolam ikan dipengaruhi oleh nilai konsentrasi amonia yang masuk dan keluar kolam, serta amonia yang berasal dari kolam itu sendiri. Amonia yang ada di dalam kolam berasal dari feses dan sisa pakan ikan yang besarannya dipengaruhi oleh populasi ikan, laju pemberian pakan (feeding rate), bobot ikan, fraksi $\mathrm{N}$ di dalam pakan dan feses, dan jumlah pakan yang tidak dikonsumsi. Amonia yang keluar dari kolam bersama dengan aliran air akan diolah dalam filter mekanik, kemudian dilanjutkan oleh filter biologi. Dalam filter biologi, sebagian besar amonia akan dioksidasi melalui proses nitrifikasi dan sisanya yang tidak terolah akan kembali masuk ke dalam kolam ikan.

Konsentrasi amonia yang ada di kolam ikan diperoleh dari Persamaan 1 (Weatherley, 1982).

$$
V_{F} \frac{d C_{0}}{d t}=F\left(C_{i}-C_{0}\right)+A \delta(t) V_{F} \quad(\text { Persamaan } 1)
$$

di mana:

$V_{F} \quad$ : volume air kolam (L)

$C_{i} \quad$ : konsentrasi amonia yang masuk ke kolam ikan (mg/L)

$\mathrm{C}_{0} \quad$ : konsentrasi amonia yang keluar dari kolam ikan (mg/L)

$\mathrm{F} \quad$ : laju resirkulasi (L/jam)

$\mathrm{A} \delta(\mathrm{t})$ : fungsi impuls, yaitu amonia yang berasal dari feses ikan dan sisa pakan (mg/L/jam)

Konsep kesetimbangan massa yang sama jugadigunakan untuk menghitung konsentrasi amonia di filter mekanik dan filter biologi, yaitu Persamaan 2 yang dimodifikasi dari persamaan kesetimbangan amonia pada filter biologi (Weatherley, 1982).

$$
\mathrm{V}_{\mathrm{B}} \frac{\mathrm{dC_{i }}}{\mathrm{dt}}=\mathrm{F}\left(\mathrm{C}_{0}-\mathrm{C}_{\mathrm{i}}\right)-\varepsilon \mathrm{C}_{0}-k \mathrm{C}_{\mathrm{i}} \mathrm{V}_{\mathrm{B}}(\text { Persamaan } 2)
$$

di mana:

$V_{B}$ : volume filter biologi $(L)$

$\varepsilon$ : fraksi pengolahan amonia oleh filter mekanik

k : konstanta laju oksidasi orde pertama dari amonia menjadi nitrit $(1 / j a m)$

\section{Validasi Model}

Validasi model dilakukan dengan membandingkan data hasil simulasi model dengan data kualitas air dari penelitian budidaya ikan gurami dengan sistem resirkulasi yang dilakukan oleh Maishela (2016) dengan menggunakan uji mean absolute percentage error (MAPE). Uji M APE (Persamaan 3) digunakan untuk mengetahui kesesuaian data hasil simulasi model dengan data aktual yang diperoleh dengan membagi nilai eror absolut pada setiap periode dengan nilai yang sebenarnya.

$$
\text { MAPE }=\frac{1}{n} \sum \frac{\left|x_{m}-x_{d}\right|}{x_{d}} \times 100 \quad(\text { Persamaan 3) }
$$

di mana:

$X_{m}:$ data hasilsimulasi

$X_{d}:$ data sebenarnya (hasil eksperimen)

$\mathrm{n}$ : periode/jumlah data

Kriteria ketepatan model dengan uji M APE bernilai sangat tepat jika persentase eror kurang dari 5\% bernilai tepat jika berada dalam rentang $5 \% 10 \%$ dan bernilai kurang tepat jika lebih dari $10 \%$ (Lomauro \& Bakshi, 1985).

\section{HASIL DAN BAHASAN}

\section{Pengaruh Laju Resirkulasi Terhadap Konsentrasi Amonia}

Konsentrasi amonia di kolam ikan sangat dipengaruhi oleh laju resirkulasi. Pada simulasi model, variasi laju resirkulasi yang digunakan yaitu 5, 10, 20, 50, dan 75 L/jam. Gambar 2 memperlihatkan pengaruh laju resirkulasi terhadap konsentrasi amonia di kolam 


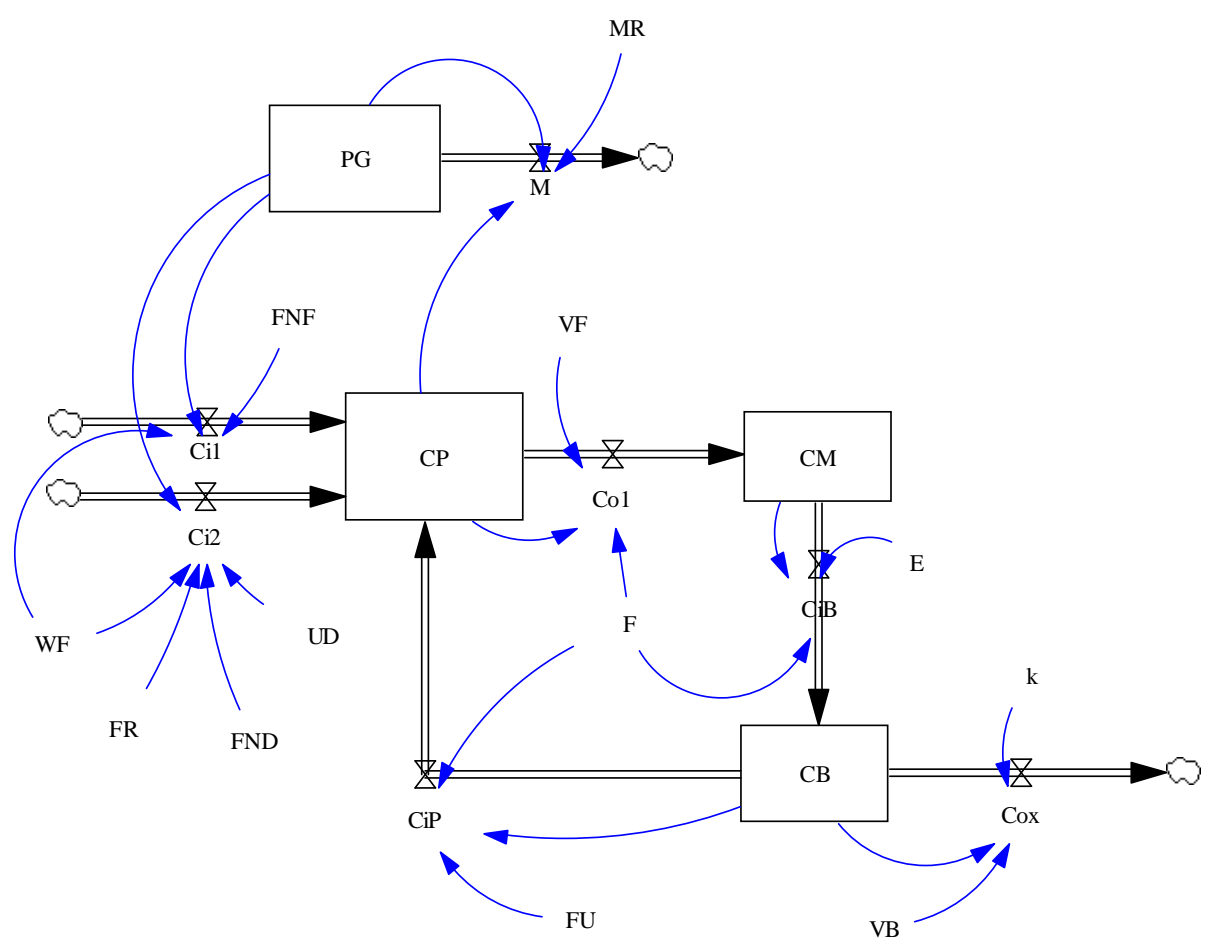

Keterangan (Note): PG: Populasi gurami di kolam (population of gouramy in fish pond); CP: konsentrasi amonia di kolam ikan (ammonia concentration in fish pond); CM: konsentrasi amonia di filter mekanik (ammonia concentration in mechanical filter); CB: konsentrasi amonia di fiter biologi (ammonia concentration in biological filter); M: kematian (mortality); Ci1: amonia dari feses (ammonia from feces); Ci2: amonia dari sisa pakan (ammonia from uneaten fish food); Co 1: amonia keluar kolam (ammonia out of pond); CiB: amonia hasil filtrasi (ammonia from filtration); Cox: amonia teroksidasi (oxidation of ammonia); CiP: amonia tidak terolah (untreated ammonia); MR: laju kematian (mortality rate); FNF: fraksi $\mathrm{N}$ di feses (fraction of N in feces); WF: bobot ikan (fish weight); FR: laju pemberian pakan (feeding rate); FND: fraksi $\mathrm{N}$ di pakan (fraction of $\mathrm{N}$ in fish food); UD: pakan yang tidak dikonsumsi (uneaten fish food); VF: volume air kolam (fish pond volume); F: laju resirkulasi (recirculation rate); E: fraksi pengolahan amonia oleh filter mekanik (fraction of ammonia removal by mechanical filter); $k$ : konstanta laju orde pertama oksidasi amonia (oxidation rate for ammonia); VB: volume filter biologi (volume of biological filter); FU: fraksi amonia tidak terolah (fraction of untreated ammonia)

Gambar 1. Formulasi model dinamika sistem untuk evaluasi kualitas air pada budidaya ikan gurami dengan sistem resirkulasi.

Figure 1. Formulation of a system dynamics model for water quality evaluation in a gouramy culture with a recirculation system.

ikan setelah melalui proses filtrasi. Semakin tinggi laju resirkulasi, maka konsentrasi amonia di kolam ikan akan semakin rendah. Menurut situs Obat Penggemuk Ternak (2021), dalam sistem budidaya ikan dengan resirkulasi, laju resirkulasi air yang dianjurkan adalah satu siklus per jam. Dengan demikian, laju resirkulasi yang mendekati volume air kolam akan memberikan hasil yang optimal baik dari segi sintasan ikan maupun pertumbuhannya. Dari hasil simulasi model pada Gambar 2, terlihat bahwa laju resirkulasi 50 L/jam dan 75 L/jam memberikan hasil yang optimal karena mampu menurunkan konsentrasi amonia dalam kolam ikan hingga 0,04 mg/L. Namun terkait dengan penggunaan daya listrik, laju resirkulasi 50 L/jam lebih direkomendasikan untuk menekan biaya listrik yang diperlukan.

Peningkatan laju resirkulasi dapat meningkatkan jumlah air yang mengalir di dalam sistem. Hal ini menyebabkan terjadinya peningkatan beban hidrolik (hydraulic load) dan efisiensi penyisihan amonia juga akan menjadi lebih tinggi (Chen et al., 2019). Peningkatan laju resirkulasi air juga akan meningkatkan turbulansi pada air, sehingga proses nitrifikasi akan semakin meningkat (Chen et al., 2006). Dapat dikatakan bahwa pengaruh laju resirkulasi terhadap penyisihan amonia adalah dengan peningkatan jumlah air yang mengalir pada waktu 


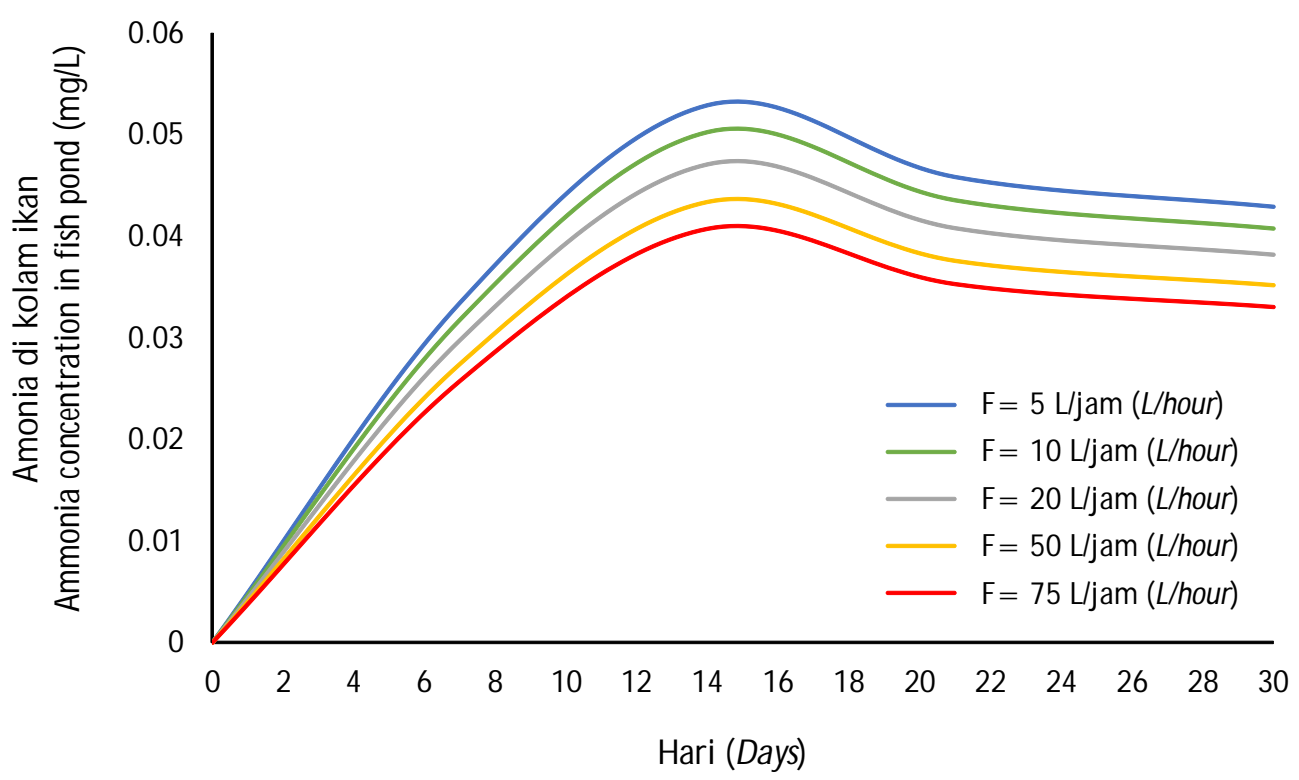

Gambar 2. Pengaruh laju resirkulasi (F) terhadap konsentrasi amonia di kolam ikan.

Figure 2. Effect of recirculation rate (F) on ammonia concentration in fish pond.

tertentu akan meningkatkan proses nitrifikasi yang berdampak pada perbaikan kualitas air dalam sistem.

Gambar 2 juga menunjukkan bahwa konsentrasi amonia meningkat dari hari ke-1 hingga hari ke-15 simulasi. Hal ini berkaitan dengan semakin meningkatnya limbah organik yang berasal dari proses metabolisme seiring dengan meningkatnya pertumbuhan ikan. Bahan buangan dari proses metabolisme ikan cenderung asam sehingga memengaruhi peningkatan konsentrasi amonia (Verawati et al., 2015). Selain itu, limbah organik yang berasal dari sisa pakan yang tidak dikonsumsi juga berkontribusi dalam peningkatan konsentrasi amonia selama dua minggu pertama simulasi. Pertambahan bobot ikan pada dua minggu pertama menyebabkan penambahan dosis pakan. Perubahan kondisi lingkungan atau adaptasi ikan pada lingkungan baru ini dapat menyebabkan stres pada ikan yang berdampak pada penurunan nafsu makan, sehingga amonia yang dihasilkan dari sisa pakan juga akan meningkat. Selain itu, biomassa bakteri pengoksidasi amonia belum optimal karena dibandingkan dengan jenis bakteri yang lain, bakteri nitrifikasi tumbuh lebih lambat, sehingga konsentrasi amonia meningkat lebih cepat daripada peningkatan po pulasi bakteri nitrifikasi. Proses oksidasi amonia menjadi nitrit biasanya memakan waktu 2-6 minggu, bergantung pada suhu air kolam budidaya (Hastuti, 2004).

Peningkatan konsentrasi amonia dalam sistem akan memicu pertumbuhan bakteri nitrifikasi yang akan mengoksidasi amonia yang sangat beracun menjadi nitrit yang sedikit kurang beracun (Web-goldfish,
2020). Aktivitas bakteri nitrifikasi mulai meningkat sejak hari ke-16 yang ditandai dengan penurunan konsentrasi amonia secara bertahap hingga hari ke30 simulasi. Hal ini menunjukkan bahwa bakteri pengoksidasi amonia yang berperan dalam tahap pertama proses nitrifikasi sudah bekerja optimal dalam menurunkan konsentrasi amonia mulai hari ke16 atau minggu ke-3.

Pada simulasi model ini, tiga jenis filter yang digunakan sekaligus adalah ijuk, spons, dan pecahan karang (Maishela, 2016). Filter ijuk dan spons berperan sebagai filter mekanik. ljuk memiliki struktur yang berongga, sehingga ketika feses dan sisa pakan yang terbawa oleh aliran air melewati ijuk, partikel feses dan sisa pakan akan terpecah menjadi ukuran yang lebih kecil. Selanjutnya, feses dan sisa pakan yang melewati spons akan disaring kembali dengan poripori yang lebih halus menjadi limbah yang larut dalam air. Limbah feses dan sisa pakan yang telah larut dalam air kemudian melewati pecahan karang. Filter terakhir ini berfungsi sebagai filter biologi karena pecahan karang memiliki banyak lubang yang dapat dimanfaatkan oleh bakteri untuk hidup dan melakukan proses nitrifikasi yang mengubah senyawa amonia menjadi nitrit, kemudian menjadi nitrat. Penurunan konsentrasi amonia pada hari ke-16 menunjukkan bahwa proses nitrifikasi yang dilakukan oleh bakteri yang berasosiasi dengan substrat filter mulai bekerja secara optimal pada hari tersebut (Gambar 2).

Konsentrasi amonia di kolam sangat memengaruhi sintasan ikan gurami. Amonia di dalam perairan terdapat dalam dua bentuk, yaitu amonia terionisasi 
atau ion amonium $\left(\mathrm{NH}_{4}^{+}\right.$) yang tidak beracun dan amonia tidak terionisasi $\left(\mathrm{NH}_{3}\right)$ yang bersifat racun bagi ikan (Bregnballe, 2015). Sawyer \& McCarty (1978) dalam Effendi (2003) menyebutkan bahwa konsentrasi amonia bebas yang tidak terionisasi $\left(\mathrm{NH}_{3}\right)$ pada perairan tawar sebaiknya tidak lebih dari $0,02 \mathrm{mg} / \mathrm{L}$. jika kadar amonia bebas lebih dari $0,02 \mathrm{mg} / \mathrm{L}$ perairan akan bersifat toksin bagi beberapa jenis ikan. Kemudian menurut Affiati \& Lim dalam Nirmala \& Rasmawan (2010), pertumbuhan benih gurami masih baik pada konsentrasi amonia di dalam air sebesar 0,0-0,12 mg/L dan kurang dari 0,1 mg/L (Boyd, 1990). Konsentrasi amonia tidak terionisasi yang mematikan $\left(\mathrm{LC}_{50}\right)$ untuk ikan berkisar dari 0,56 hingga 2,37 mg/L dalam waktu 24-96 jam setelah paparan (Environment Canada, 2001). Pada konsentrasi $0,04 \mathrm{mg} / \mathrm{L}$ amonia dapat menghasilkan mortalitas $5 \%$ dan penurunan pertumbuhan ikan budidaya 20\% Dari beberapa referensi tersebut data kematian $5 \%$ untuk konsentrasi amonia $0,04 \mathrm{mg} / \mathrm{L}$ digunakan dalam simulasi model karena angka tersebut merupakan batas konsentrasi amonia terendah yang dapat menyebabkan kematian ikan.

Data ini digunakan untuk memperkirakan berapa ekor ikan gurami yang akan mati selama periode simulasi dengan jumlah populasi ikan sebanyak 50 ekor padat $=0$ (Maishela, 2016). Gambar 2 memperlihatkan bahwa mulai hari ke-14 hingga hari ke-17 semua variasi laju resirkulasi menghasilkan konsentrasi amonia yang melebihi ambang batas ( $\geq 0,04 \mathrm{mg} / \mathrm{L})$. Hal ini berpotensi menyebabkan kematian pada ikan gurami. Kemudian, konsentrasi amonia menurun sampai dengan hari ke-30.
Gambar 3 menunjukkan pengaruh laju resirkulasi terhadap populasi ikan gurami. Laju resirkulasi 5 dan 10 L/jam akan menurunkan populasi ikan sebanyak $14,26 \%$ sampai dengan hari ke-30. Untuk laju resirkulasi 20 L/jam, populasi ikan akan menurun sejumlah 9,75\% pada hari ke-21 dan seterusnya jumlah ikan akan tetap. Untuk laju resirkulasi 50 dan 75 L/jam, populasi ikan akan menurun sejumlah 5\%pada hari ke-14, selanjutnya jumlah ikan akan tetap. Dengan demikian, laju resirkulasi 50 dan 75 L/jam memberikan hasil yang optimal untuk konsentrasi amonia yang aman untuk sintasan ikan gurami.

Variasi laju resirkulasi memengaruhi sintasan ikan gurami. Zonneveld et al. (1991) mengatakan bahwa semakin tinggi laju resirkulasi yang diberikan maka kekuatan arus yang dihasilkan akan semakin tinggi dan konsentrasi oksigen serta sarana pengeluaran limbah metabolis memeningkat. Distribusi oksigen yang merata akan digunakan oleh bakteri untuk proses nitrifikasi. Dari Gambar 3 dapat dilihat bahwa laju resirkulasi yang semakin tinggi menghasilkan sintasan yang lebih tinggi pula. Hal ini diakibatkan oleh semakin tinggi laju resirkulasi air maka limbah pada kolam ikan akan lebih cepat terangkut keluar sehingga kualitas air akan tetap terjaga dan dapat meningkatkan kualitas hidup ikan. Sedangkan laju resirkulasi yang terlalu rendah akan mengakibatkan produksi ikan menurun, kandungan oksigen dalam air menjadi berkurang, dan sisa pakan serta limbah metabolisme tidak terolah dengan baik (Afrianto \& Evy, 1988). Sirkulasi adalah salah satu cara untuk memperbaiki kualitas air. Kualitas air yang baik akan manjadikan ikan tumbuh dengan baik dan optimal.

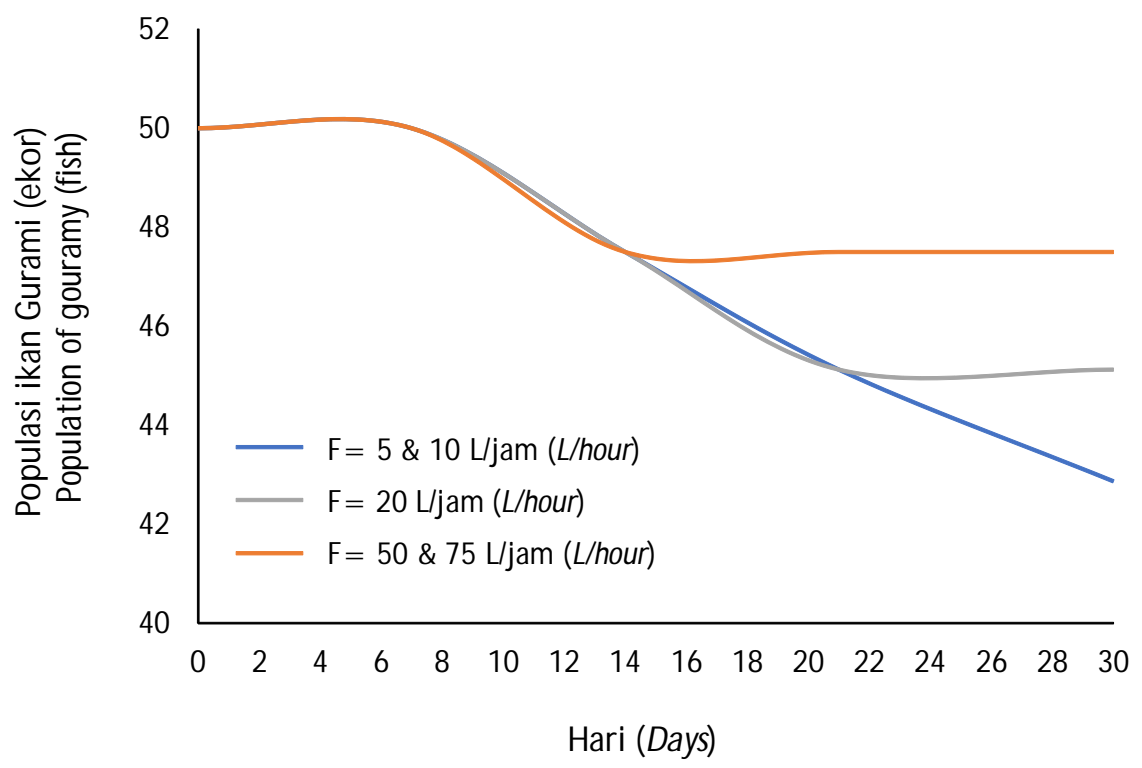

Gambar 3. Pengaruh laju resirkulasi (F) terhadap populasi ikan gurami.

Figure 3. Effect of recirculation rate (F) on gouramy populations. 


\section{Validasi Model}

Validasi model dilakukan dengan menggunakan uji MAPE (Persamaan 3). Uji ini dapat digunakan untuk menilai keakuratan hasil prediksi model terhadap nilai yang sebenarnya. Perbandingan nilai konsentrasi amonia tidak terionisasi sebenarnya dari hasil penelitian (Maishela, 2016) dan hasil simulasi model dinamika sistem pada laju resirkulasi 50 L/jam ditunjukkan dalam Tabel 2 dengan hasil uji MAPE sebesar 8,6\%eror. Hal ini menunjukkan bahwa model dinamika sistem untuk evaluasi kualitas air pada budidaya ikan gurami tepat atau valid, sehingga dapat diaplikasikan.

Hasil simulasi model ini memperlihatkan bahwa pada kondisi yang diberikan, budidaya ikan gurami dengan sistem resirkulasi dapat dilakukan. Pengoperasian sistem resirkulasi dalam mengendalikan, memelihara, dan mempertahankan kualitas air menandakan bahwa sistem resirkulasi memiliki hubungan yang erat dengan proses perbaikan kualitas air dalam pengolahan air limbah budidaya ikan. Pemilihan filter yang sederhana dan murah juga memberikan keuntungan secara ekonomis. Namun, pemeriksaan dan perawatan berkala perlu selalu dilakukan untuk menjamin keberlangsungan hidup ikan gurami dan sistem resirkulasi ini.

\section{KESIMPULAN}

Kualitas air khususnya parameter amonia pada budidaya ikan gurami dengan sistem resirkulasi dapat dievaluasi dengan menggunakan model dinamika sistem dengan persentase eror sebesar 8,6\% Dari hasil simulasi model, laju resirkulasi 50 L/jam dan 75 L/jam memberikan hasil yang optimal dalam konsentrasi amonia dan sintasan ikan gurami, namun laju resirkulasi 50 L/jam lebih direkomendasikan untuk menekan biaya listrik. Pada simulasi model dengan kondisi yang diberikan, konsentrasi amonia di dalam suatu sistem resirkulasi dapat diketahui, sehingga informasi dan panduan dalam pemantauan kualitas air, khususnya amonia, dalam sistem resirkulasi budidaya ikan gurami dapat diperoleh. Diperlukan pemodelan yang lebih kompleks untuk dapat menyimulasikan parameter kualitas air yang lain seperti oksigen terlarut, $\mathbf{p H}$, dan suhu yang memengaruhi kualitas air dan sintasan ikan gurami dalam sistem budidaya resirkulasi.

\section{UCAPAN TERIMA KASIH}

Penelitian ini merupakan bagian dari kegiatan Program Partenariat Hubert Curien (PHC) Nusantara 2018 yang berjudul Transfer of Ecotron Technology to Ensure the Sustainability of Aquaculture Industries with Optimized Water Quality. Ucapan terima kasih terutama ditujukan kepada pemberi dana penelitian. Ucapan terima kasih juga disampaikan kepada pihak-pihak yang membantu pelaksanaan penelitian dan penulisan naskah.

\section{DAFTAR ACUAN}

Afrianto, E. \& Evy, L. (1988). Beberapa metode budidaya ikan. Yogyakarta: Kanisius, $103 \mathrm{hlm}$.

Benli, A.Ç.K., Köksal, G., \& Özkul, A. (2008). Sublethal ammonia exposure of nile tilapia (Oreochromis niloticus L.): Effects on gill, liver and kidney histology. Chemosphere, 72(9), 1355-1358.

Boyd, C.E. (1990). Water quality in ponds for aquaculture. Alabama: Auburn University. 482 pp.

Bregnballe, J. (2015). A guide to recirculation aquaculture. Denmark: FAO and EUROFISH. 100 pp.

BSN. (2000). Standar Nasional Indonesia. Produksi benih ikan gurame (Osphronemus goramy, Lac) kelas benih sebar. Jakarta: Badan Standardisasi Nasional, $10 \mathrm{hlm}$.

Budiardi, T., Ginting, R.A.N., \& Hadiroseyani, Y. (2011). Produksi benih gurami Osphronemus goramy Lac. dengan tingkat pergantian air berbeda. Jurnal Akuakultur Indonesia, 10(2), 144-153.

Chen, S., Ling, J., \& Blancheton, J.P. (2006). Nitrification kinetics of biofilm as affected by water quality factors. Aquacultural Engineering, 34(3), 179-197.

Tabel 2. Perbandingan konsentrasi amonia sebenarnya dan hasil simulasi

Table 2. Comparison of ammonia concentration from actual and simulated farming systems

\begin{tabular}{lcccc}
\hline \multicolumn{1}{c}{$\begin{array}{c}\text { Konsentrasi amonia } \\
\text { Ammonia concentration }\end{array}$} & I & II & III & IV \\
\cline { 2 - 5 } & 0.0300 & 0.0471 & 0.0414 & 0.0386 \\
\hline $\begin{array}{l}\text { Hasil sebenarnya } \\
\begin{array}{l}\text { Actual value (mg/L) } \\
\text { Hasil simulasi } \\
\text { Simulated value (mg/L) }\end{array}\end{array}$ & 0.0275 & 0.0434 & 0.0376 & 0.0352 \\
\hline
\end{tabular}

Sumber (Source): * Maishela (2016) 
Chen, Z., Chang, Z., Zhang, L., Jiang, Y., Ge, H., Song, X., Chen, S., Zhao, F., \& Li, J. (2019). Effects of water recirculation rate on the microbial community and water quality in relation to the growth and survival of white shrimp (Litopenaeus vannamei). BMC Microbiology, 19(1), 1-15.

Effendi, H. (2003). Telaah kualitas air bagi pengelolaan sumber daya dan lingkungan perai ran. Yogyakarta: Kanisius. $257 \mathrm{hlm}$.

Environment Canada. (2001). Priority substances list assessment report:Ammonia in the aquatic environment. Canada.

Fadhil, R., Endan, J., Taip, F.S., \& Bin Hj Ja'afar, M.S. (2010). Teknologi sistem akuakultur resirkulasi untuk meningkatkan produksi perikanan darat di Aceh: Suatu tinjauan. Proceeding of Aceh Development International Conference 2010.hlm. 826-833.

Fletcher, R. (2020). Results from Norway's first landbased salmon farm | The fish site. The Fish Site.https://thefishsite.com/articles/results-fromnorways-first-land-based-salmon-farm. Tanggal akses: 10 November 2020.

Forrester, J.W. (1994). System dynamics, systems thinking, and soft OR. System Dynamics Review, 10(23), 245-256.

Fuchs, H.U. (2006). System dynamics modeling in science and engineering. Invited Talk at the System Dynamics Conference at the University of Puerto Rico Resource Center for Science and Engineering. Mayaguez, December 8-10, 2006.

Gardner Pinfold Consultants Inc. (2019). State of salmon aquaculture technologies. Canada: Fisheries and Oceans Canada, 64 pp.

Hastuti, S. (2004). Respons fisiologis ikan gurami (Osphronemus gouramy, Lac.) yang diberi pakan mengandung kromium-ragi terhadap penurunan suhu lingkungan.Tesis. Bogor. Pascasarjana Institut Pertanian Bogor.

Hutchinson, W., Jeffrey, M., O'Sullivan, D. (Dos), Casement, D., \& Clarke, S. (2004). Recirculating aquaculture systems minimum standards for design, construction and management. Report number: RAS MSDCM V2 040220. Australia:Inland Aquaculture Association of South Australia Inc.

Labbé, L., Lefèvre, F., Bugeon, J., Fostier, A., Jamin, M., \& Gaumé, M. (2014). Conception d'un système innovant de production de truites en eau recirculée. INRA Productions Animales, 27(2), 135146.
Lekang, 0.-I. (2013). Traditional recirculation and water re-use systems. InAquaculture Engineering. Second Edition. US: John Wiley \& Sons, Ltd. p. 190-200.

Lomauro, G.J. \& Bakshi, A.S. (1985). Finite element analysis of moisture diffusion in stored foods. Journal of Food Science, 50(2), 392-396.

López-Alvarado, J. (1997). Aquafeeds and the environment. InCIHEAM - Options Mediterraneennes.France: CIHEAM.

Maishela, B.F. (2016). Pengaruh susunan filter terhadap konsentrasi $\mathrm{N}$ dan $\mathrm{P}$ pada pendederan ikan gurame (Osphronemus gouramy) dengan sistem resirkulasi. Skripsi. Bandar Lampung. Universitas Lampung.

McDonald, M.E., Tikkanen, C.A., Axler, R.P., Larsen, C.P., \& Host, G. (1996). Fish simulation culture model (FIS-C): A bioenergetics based model for aquacultural wasteload application. Aquacultural Engineering, 15(4), 243-259.

Meyer, S. (2018). Sustainable aquaculture Germany, Get to know your future partners!.Jerman: Future Ocean-Kiel Marine Science, 68 pp.

Miller, J. A. (2018). RAS in the USA?: Fad or future??. https://www.globalseafood.org/advocate/ras-inthe-usa-fad-or-future/. Tanggal akses 10 Oktober 2020.

Nirmala, K. \& Rasmawan. (2010). Kinerja pertumbuhan ikan gurame (Osphronemus goramy Lac.) yang dipelihara pada media bersalinitas dengan paparan medan listrik. Jurnal Akuakultur Indonesia, 9(1), 4655.

Obat Penggemuk Ternak. (2021). Design tangki budidaya dalam sistem recirculating aquaculture system. Https://Obatpenggemukternak.Com/. Tanggal akses: 10 Oktober 2020.

Ogbonna, J. \& Chinomso, A. (2010). Determination of the concentration of ammonia that could have lethal effect on fish pond. ARPN Journal of Engineering and Applied Sciences, 5(2), 1-5.

Ripple, W. (2003). Nitrification basics for aerated Lagoon operators.4th Annual Lagoon Operators Round Table Discussion Ashland WWTF.http:// www.lagoonsonline.com/ripple.htm. Tanggal akses: 22 Oktober 2020.

Suresh, A.V. \& Lin, C.K. (1992). Effect of stocking density on water quality and production of red tilapia in a recirculated water system. Aquacultural Engineering, 11(1), 1-22. 
Tanjung, L.R. \& Pilo, J. (2015). Ikan gurami Padang dan teknik budi daya Jhonly Pilo. Jakarta: LIPI Press, $123 \mathrm{hlm}$.

Verawati, Y., Muarif, \& Mumpuni, F.S. (2015). Pengaruh perbedaan padat penebaran terhadap pertumbuhan dan kelangsungan hidup benih ikan gurami (Osphronemus goramy) pada sistem resirkulasi. Jurnal Mina Sains, 1(1), 6-12.

Weatherley, L.R. (1982). Application of simple dynamic response analysis to a recirculating aquaculture system: A preview. Aquacultural Engineering, 1(2), 93-113.

Web-goldfish. (n.d.). What is aquarium filtration?. https://www.web-goldfish.com/aquarium-water-parameters/aquarium-filtration-basics/. Tanggal akses: 10 Oktober 2020.

Zonneveld, N., Huisman, E.A., \& Boon, J.H. (1991). Prinsip-prinsip budidaya ikan. Jakarta: Gramedia Pustaka Utama, $318 \mathrm{hlm}$.

Afrianto, E. \& Evy, L. (1988). Beberapa metode budidaya ikan. Yogyakarta: Kanisius, $103 \mathrm{hlm}$.

Benli, A.Ç.K., Köksal, G., \& Özkul, A. (2008). Sublethal ammonia exposure of nile tilapia (Oreochromis niloticus L.): Effects on gill, liver and kidney histology. Chemosphere, 72(9), 1355-1358.

Boyd, C. E. (1990). Water Quality in Ponds for Aquaculture. Alabama: Auburn University. $482 \mathrm{hlm}$.

Bregnballe, J. (2015). A Guide to Recirculation Aquaculture. Denmark: FAO and EUROFISH. $100 \mathrm{hlm}$.

BSN. (2000). Standar Nasional Indonesia. Produksi benih ikan gurame (Osphronemus goramy, Lac) kelas benih sebar. Jakarta: Badan Standardisasi Nasional. $10 \mathrm{hlm}$.

Budiardi, T., Ginting, R. A. N., \& Hadiroseyani, Y. (2011). Produksi benih gurami Osphronemus goramy Lac . dengan tingkat pergantian air berbeda. Jurnal Akuakultur Indonesia, 10(2), 144153.

Chen, S., Ling, J., \& Blancheton, J. P. (2006). Nitrification kinetics of biofilm as affected by water quality factors. Aquacultural Engineering, 34(3), 179197.

Chen, Z., Chang, Z., Zhang, L., Jiang, Y., Ge, H., Song, X., Chen, S., Zhao, F., \& Li, J. (2019). Effects of water recirculation rate on the microbial community and water quality in relation to the growth and survival of white shrimp (Litopenaeus vannamei). BMC Microbiology, 19(1), 1-15.

Effendi, H. (2003). Telaah Kualitas Air Bagi Pengelolaan Sumber Daya dan Lingkungan Perairan. Yogyakarta: Kanisius. $257 \mathrm{hlm}$.
Environment Canada. (2001). Priority substances list assessment report:Ammonia in the Aquatic Environment. Kanada.

Fadhil, R., Endan, J., Taip, F. S., \& Bin Hj Ja'afar, M. S. (2010). Teknologi Sistem Akuakultur Resirkulasi untuk Meningkatkan Produksi Perikanan Darat di Aceh: Suatu Tinjauan. Proceeding of Aceh Development International Conference 2010. 826-833.

Fletcher, R. (2020). Results from Norway's first landbased salmon farm | The Fish Site. The Fish Site Site.https://thefishsite.com/articles/results-fromnorways-first-land-based-salmon-farm. Tanggal akses: 10 November 2020.

Forrester, J. W. (1994). System dynamics, systems thinking, and soft OR. System Dynamics Review, $10(2-3), 245-256$.

Fuchs, H. U. (2006). System Dynamics Modeling in Science and Engineering. Invited Talk at the System Dynamics Conference at the University of Puerto Rico Resource Center for Science and Engineering, Mayaguez, December 8-10, 2006.

Gardner Pinfold Consultants Inc. (2019). State of Salmon Aquaculture Technologies.Kanada: Fisheries and Oceans Canada. $64 \mathrm{hlm}$.

Hastuti, S. (2004). Respons Fisiologis Ikan Gurami (Osphronemus gouramy, Lac.) yang Diberi Pakan Mengandung Kromium-Ragi terhadap Penurunan Suhu Lingkungan.[Thesis]. Bogor. Pascasarjana Institut Pertanian Bogor.

Hutchinson, W., Jeffrey, M., O'Sullivan, D. (Dos), Casement, D., \& Clarke, S. (2004). Recirculating Aquaculture Systems M inimum Standards for Design, Construction and Management.Report number: RAS MSDCM V2 040220. Australia:Inland Aquaculture Association of South Australia Inc.

Labbé, L., Lefèvre, F., Bugeon, J., Fostier, A., Jamin, M., \& Gaumé, M. (2014). Conception d'un système innovant de production de truites en eau recirculée. INRA Productions Animales, 27(2), 135146.

Lekang, 0.-I. (2013). Traditional Recirculation and Water Re-use Systems. In Aquaculture Engineering, Second Edition. US: John Wiley \& Sons, Ltd. 190200.

Lomauro, G. J., \& Bakshi, A. S. (1985). Finite Element Analysis of Moisture Diffusion in Stored Foods. Journal of Food Science, 50(2), 392-396.

López-Alvarado, J. (1997). Aquafeeds and the environment. In CIHEAM - Options M editerraneennes. Paris: CIHEAM. 
Maishela, B. F. (2016). Pengaruh Susunan Filter terhadap Konsentrasi $\mathrm{N}$ dan $\mathrm{P}$ pada Pendederan Ikan Gurame (Osphronemus gouramy) dengan Sistem Resirkulasi. [Skripsi]. Bandar Lampung. Universitas Lampung.

McDonald, M. E., Tikkanen, C. A., Axler, R. P., Larsen, C. P., \& Host, G. (1996). Fish simulation culture model (FIS-C): A bioenergetics based model for aquacultural wasteload application. Aquacultural Engineering, 15(4), 243-259.

Meyer, S. (2018). SUSTAINABLE AQUACULTURE GERM ANY - Get to know your future partners!. Jerman: Future Ocean-Kiel Marine Science. $68 \mathrm{hlm}$.

Nirmala, K., \& Rasmawan. (2010). Kinerja pertumbuhan ikan gurame (Osphronemus goramy Lac.) yang dipelihara pada media bersalinitas dengan paparan medan listrik. Jurnal Akuakultur Indonesia, 9(1), 46-55.

Obat Penggemuk Ternak. (2021). Design Tangki Budidaya dalam Sistem Recirculating Aquaculture System. Https://Obatpenggemukternak.Com/. Tanggal akses: 10 Oktober 2020.

Ogbonna, J., \& Chinomso, A. (2010). Determination of the concentration of ammonia that could have lethal effect on fish pond. ARPN Journal of Engineering and Applied Sciences, 5(2), 1-5.

Ripple, W. (2003). Nitrification Basics for Aerated Lagoon Operators.4th Annual Lagoon Operators Round
Table Discussion Ashland WWTF.http:// www.lago onsonline.com/ripple.htm. Tanggal akses: 22 Oktober 2020.

Suresh, A. V., \& Lin, C. K. (1992). Effect of stocking density on water quality and production of red tilapia in a recirculated water system. Aquacultural Engineering, 11(1), 1-22.

Tanjung, L. R., \& Pilo, J. (2015). Ikan Gurami Padang dan Teknik Budi Daya Jhonly Pilo. Jakarta: LIPI Press. $123 \mathrm{hlm}$.

Verawati, Y., Muarif, \& Mumpuni, F. S. (2015). Pengaruh Perbedaan Padat Penebaran terhadap Pertumbuhan dan Kelangsungan Hidup Benih Ikan Gurami (Osphronemus gouramy) pada Sistem Resirkulasi. Jurnal Mina Sains, 1(1), 6-12.

Weatherley, L. R. (1982). Application of simple dynamic response analysis to a recirculating aquaculture system - A preview. Aquacultural Engineering, 1(2), 93-113.

Web-goldfish. (n.d.). What is Aquarium Filtration?. https://www.web-goldfish.com/aquarium-water-parameters/aquarium-filtration-basics/. Tanggal akses: 10 Oktober 2020.

Zonneveld, N., Huisman, E. A., \& Boon, J. H. (1991). Prinsip-prinsip Budidaya Ikan. Jakarta: Gramedia Pustaka Utama. $318 \mathrm{hlm}$. 